\title{
Unexpected Finding in an Adult Patient Without Typical Symptoms: Huge Pseudoaneurysm Fulfilled with Thrombus
}

\section{Tipik Semptomları Olmayan Yetişkin Bir Hastada Beklenmedik Bulgu: Trombüs ile Dolu Dev Psödoanevrizma}

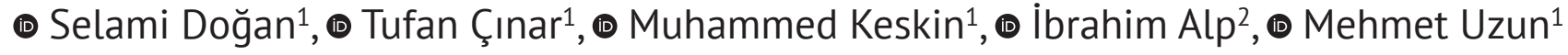 \\ ${ }^{1}$ University of Health Sciences Turkey, İstanbul Sultan 2. Abdülhamid Han Training and Research Hospital, Clinic of Cardiology, İstanbul, Turkey \\ ${ }^{2}$ University of Health Sciences Turkey, İstanbul Sultan 2. Abdülhamid Han Training and Research Hospital, Clinic of Cardiovascular Surgery, İstanbul, Turkey
}

Although most patients with left ventricle (LV) pseudoaneurysm present with chest pain, dyspnea, signs and symptoms of congestive heart failure or peripheral embolism, a few cases with a huge LV pseudoaneurysm might present without typical symptoms. In this case, we reported a huge LV pseudoaneurysm fulfilled with thrombus in an adult patient who presented without specific symptoms. A 60-year-old male patient presented to outpatient clinic with symptom of fatigue. Transthoracic electrocardiograph examination suggested a pseudoaneurysm of posterior wall of the LV, but the quality of image was poor. Cardiac magnetic resonance imaging was performed providing the presence of huge pseudoaneurysm fulfilled with thrombus on the posterolateral side of the LV. With the cardiac operation, the LV pseudoaneurysm was resected and huge thrombus was retrieved in a single piece. This case illuminates that clinicians should be aware of atypical presentation in some patients with huge LV pseudoaneurysm.

Keywords: Huge, pseudoaneurysm, thrombus

Sol ventrikül (SV) psödoanevrizması olan hastaların çoğunda göğüs ağrısı, nefes darlığı, konjestif kalp yetmezliği veya periferik emboli belirtileri ve semptomları olsa da, büyük bir SV psödoanevrizması birkaç olguda tipik semptomlar olmadan da ortaya çıkabilir. Bu olguda, tipik semptomları olmayan yetişkin bir hastada trombüs ile dolu dev bir SV psödoanevrizmasını sunduk. Altmış yaşında erkek hasta yorgunluk şikayeti ile polikliniğe başvurdu. Transtorasik ekokardiyografik inceleme SV arka duvarında psödoanevrizma ile uyumlu idi, ancak görüntü kalitesi zayıftı. Yapılan kardiyak manyetik rezonans görüntülemede SV posterolateral tarafında trombüs ile dolu büyük psödoanevrizma izlendi. Kalp ameliyatı ile SV psödoanevrizması rezeke edildi ve tek bir parça halinde büyük trombüs alındı. Bu olgu, klinisyenlerin dev SV psödoanevrizması olan bazı hastalarda atipik sunumun farkında olmaları gerektiğini göstermektedir.

Anahtar Kelimeler: Dev, psödoanevrizma, trombüs

\section{Introduction}

Left ventricle (LV) pseudoaneurysm is described as a contained sac of the myocardium, which usually develops due to acute transmural myocardial infarction (1). Although most patients with LV pseudoaneurysm present with chest pain or dyspnea or signs and symptoms of congestive heart failure or peripheral embolism, a sizable portion of such cases might be diagnosed without typical symptoms (2). In this case, we reported a LV pseudoaneurysm in an adult patient without specific symptoms.

\section{Case Report}

A 60-year-old male patient presented to outpatient clinic with symptom of fatigue. The patient had a history of coronary artery stenting due to acute myocardial infarction two years 
ago. Electrocardiography demonstrated a normal sinus rhythm, pathological Q wave in III and AVF leads without ST elevation, and $T$ wave negativity in I and AVL leads (Figure 1A). Posteroanterior chest scan did not reveal any remarkable finding (Figure 1B). He underwent a computed tomography (CT) scan of the chest due to the suspicion of Coronavirus-2019 disease. On CT, it was found that there was a huge mass on the lateral side of the LV with a diameter of $5 \times 4 \mathrm{~cm}$ (Figure 2A). To clarify the diagnosis, cardiac magnetic resonance imaging was performed providing the presence of huge pseudoaneurysm fulfilled with thrombus on the posterolateral side of the LV (Figure 2B). Transthoracic echocardiographic examination showed a LV ejection fraction of $40 \%$ and pseudoaneurysm of posterior wall but the quality of image was poor. The cardiac operation, including the resection of huge pseudoaneurysm, was planned due to the risk of peripheral embolism. The coronary angiography before cardiac surgery revealed a total occlusion of the circumflex artery after obtuse marginal artery-2 (Figure 3A). The aneurysm was diagnosed as a pseudoaneurysm because there was a discontinuation, which suggests a rupture in the wall. The most lateral wall of the aneurysm could not be imaged because of technical difficulties (Figure 3B). During cardiac operation, it was noted that pseudoaneurysm was completely fulfilled with thrombus (Figure 4A). The pseudoaneurysm was resected and huge thrombus was retrieved in a single piece (Figure 4B).

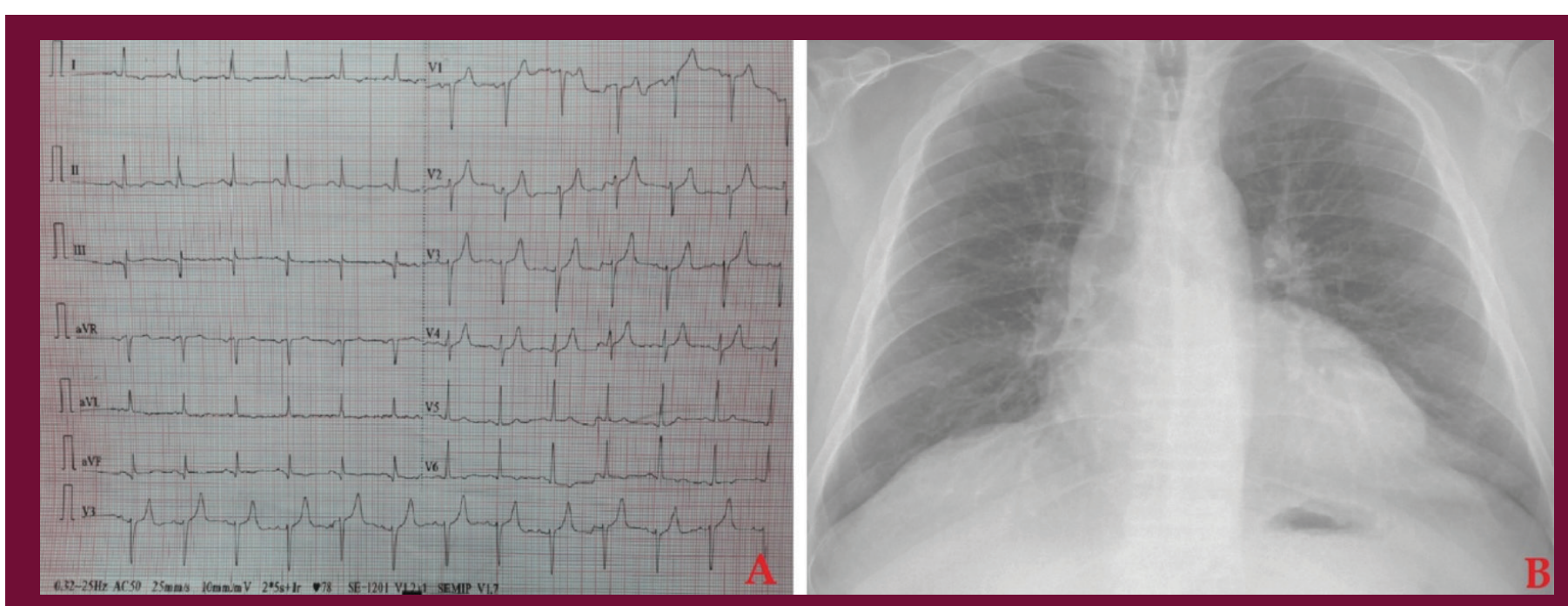

Figure 1. A) Electrocardiography of the case, B) Posteroanterior chest scan of the case

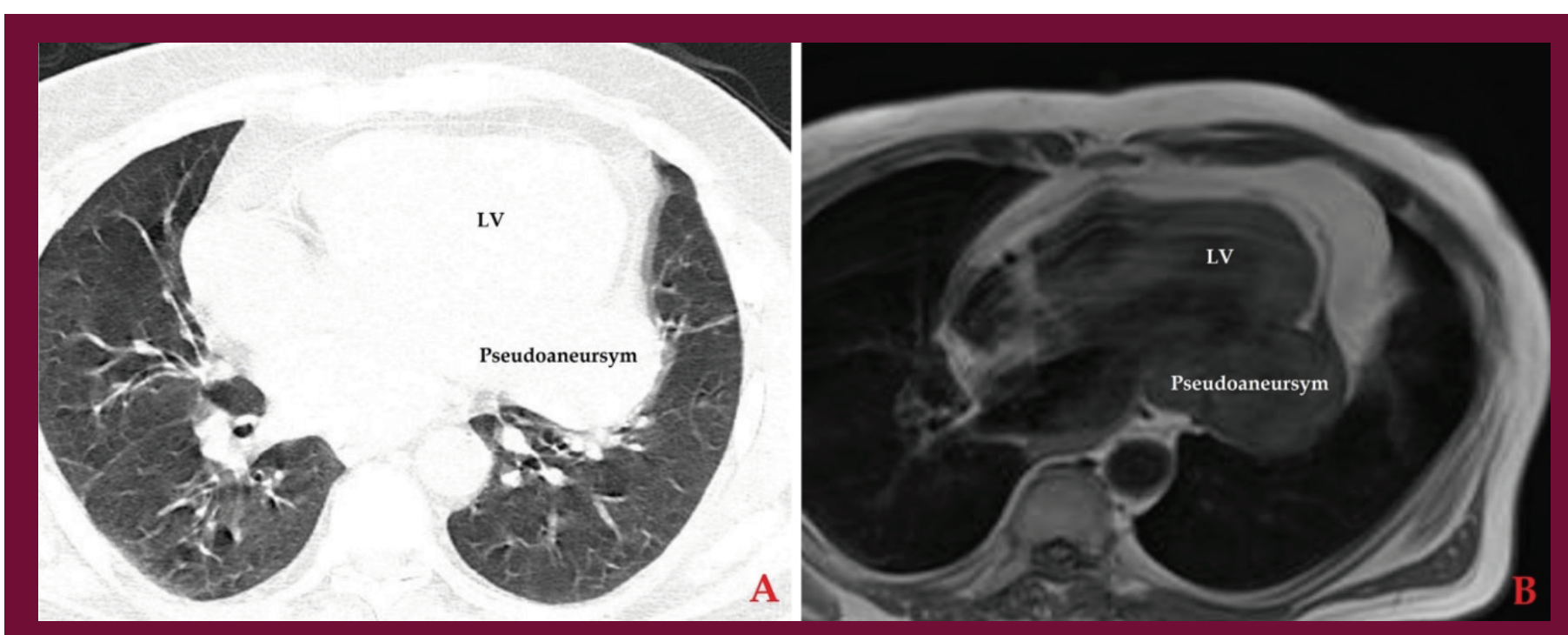

Figure 2. A) Computed tomography scan showing a mass on the LV,B) Cardiac MRI showing pseudoaneurysm on the posterolateral side of the LV LV: Left ventricle, MRI: Magnetic resonance imaging 


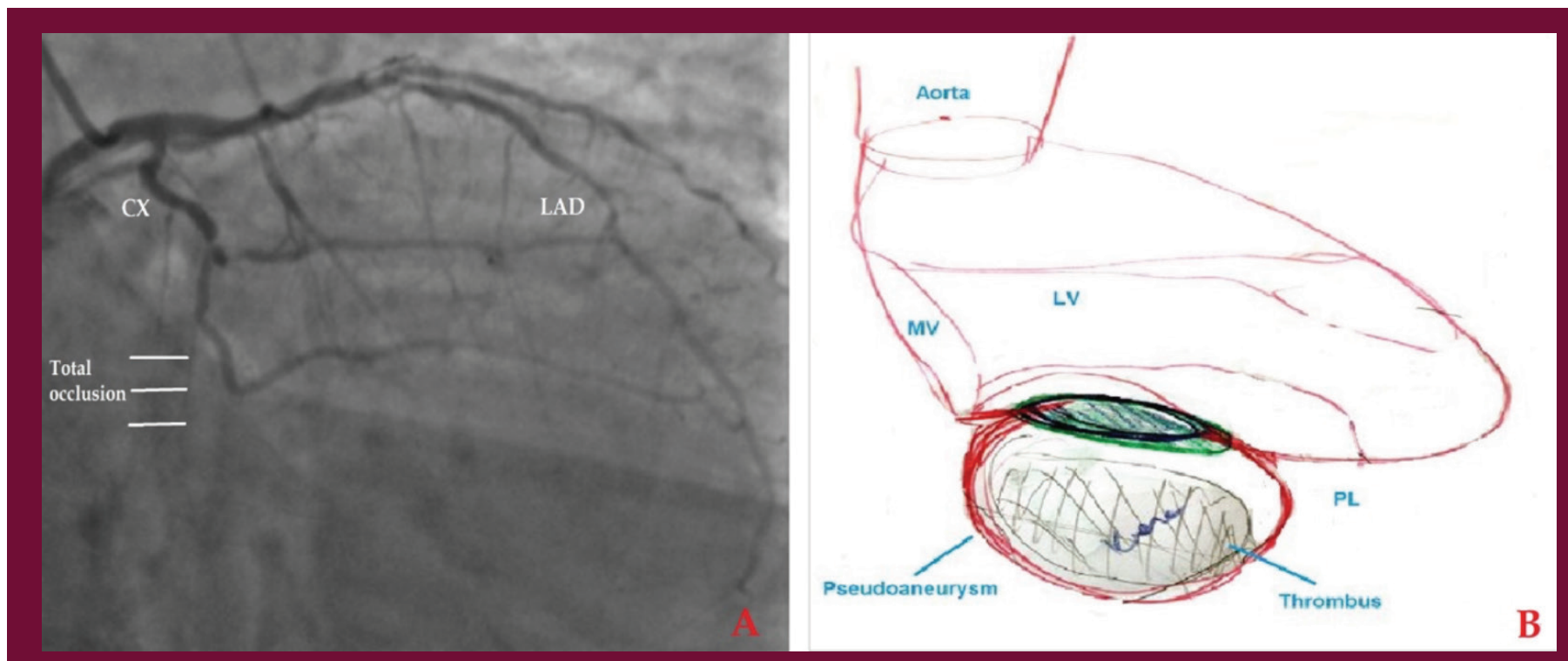

Figure 3. A) CAG showing a total occlusion of CX artery after OM-2 artery, B) Schematic diagram of the LV pseudoaneurysm CAG: Coronary angiography, CX: Circumflex artery, LV: Left ventricle, LAD: Left anterior descending artery, MV: Mitral valve, PL: Posterolateral

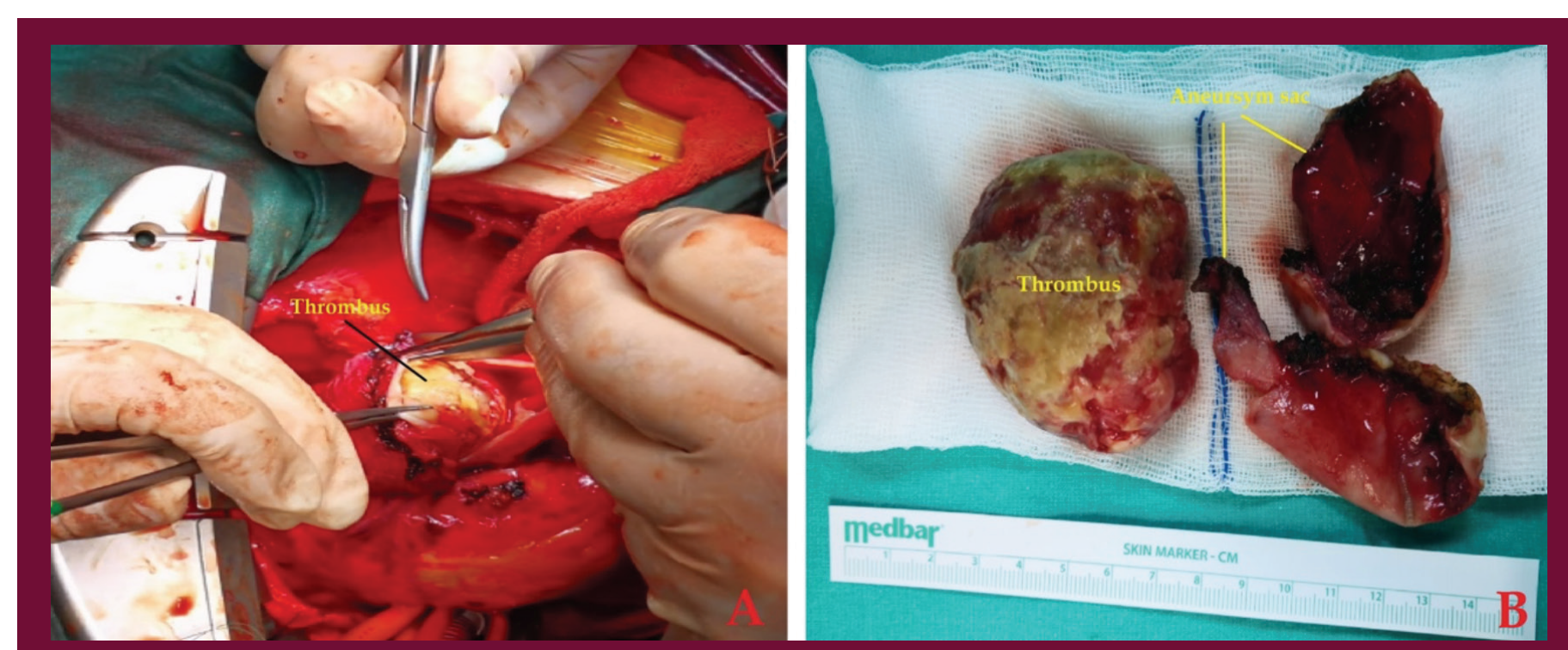

Figure 4. A) Thrombus fulfilled LV pseudoaneurysm, B) Gross specimen of LV pseudoaneurysm and huge thrombus LV: Left ventricle

\section{Discussion}

LV pseudoaneurysm, which usually develops following cardiac rupture due to transmural myocardial infarction, has a small, akinetic wall consisting of mainly two layers of pericardium and fibrous tissue that is contrast to true aneurysms composed of three layers, including endocardium, myocardium, and pericardium $(1,3)$. In our case, there was a discontinuity in the posterior wall and the wall of the aneurysm was very thin, suggesting pericardium instead of myocardial layers. The LV pseudoaneurysms have high risk of mortality because of a significant risk of sudden rupture. However, in this case, the thrombus might have prevented rupture of the wall of the pseudoaneurysm. In contrast to our case who presented without typical symptoms, most patients with LV pseudoaneurysm usually present with the signs and symptoms of heart failure, peripheral embolism, life threating arrhythmias, and chest pain (3). Therefore, the clinicians should be aware of atypical presentation in some patients with LV pseudoaneurysm. As shown in our case, in patients who presented with huge LV pseudoaneurysm 
fulfilled with thrombus should undergo a cardiac surgery, including the resection of pseudoaneurysm and retraction of thrombus, due to the risk of peripheral embolism (4).

\section{Ethics}

Informed Consent: Informed consent was obtained from the patient for publishing this case report.

Peer-review: Internally peer-reviewed.

\section{Authorship Contributions}

Concept: S.D., T.Ç., Design: S.D., T.Ç., M.K., İ.A., M.U., Data Collection or Processing: S.D., T.Ç., M.K., İ.A., M.U., Analysis or Interpretation: S.D., T.Ç., M.U., Literature Search: M.K., İ.A., Writing: S.D., T.Ç., M.U.

Conflict of Interest: No conflict of interest was declared by the authors.
Financial Disclosure: The authors declared that this study received no financial support.

\section{References}

1. Ando S, Kadokami T, Momii H, Hironaga K, Kawamura N, Fukuiama $\mathrm{T}$, et al. Left ventricular false- pseudo and pseudo aneurysm: serial observations by cardiac magnetic resonance imaging. Intern Med. 2007;46:181-185. [Crossref]

2. Şahan E, Gül M, Şahan S, Sokmen E, Guray YA, Tufekcioglu O. Pseudoaneurysm of the mitral-aortic intervalvular fibrosa. A new comprehensive review. Herz. 2015;40(Suppl 2):182-189. [Crossref]

3. Bisoyi S, Dash AK, Nayak D, Sahoo S, Mohapatra R. Left ventricular pseudoaneurysm versus aneurysm a diagnosis dilemma. Ann Card Anaesth. 2016;19:169-172. [Crossref]

4. Prifti E, Bnoacchi M, Baboci A, Giunti G, Veshti A, Demiraj A, et al. Surgical treatment of post-infarction left ventricular pseudoaneurysm: case series highlighting various surgical strategies. Ann Med Surg (Lond). 2017;16:44-51. [Crossref] 